Part of Journal of Research of the National Bureau of Standards, Volume 18, May 1937

\title{
RAPID ELECTRODEPOSITION OF IRON FROM FERROUS CHLORIDE BATHS
}

\author{
By Charles Kasper
}

\section{ABSTRACT}

Ductile iron can be deposited from ferrous chloride solutions at current densities up to $30 \mathrm{amp} / \mathrm{dm}^{2}\left(280 \mathrm{amp} / \mathrm{ft}^{2}\right)$, which is several times the customary rate of iron deposition. The temperature and acidity of the baths must be controlled within narrow limits.

Page

II. Review of literation 535

II. Review of literature

III. Scope of investigation

IV. Exploratory experiments _._. 536

1. Conditions employed _._.

2. Results

V. Quantitative tests

1. Conditions employed

2. Results _...

VI. Conclusions _...

\section{INTRODUCTION}

Many of the plates used for printing currency and securities at the U. S. Bureau of Engraving and Printing consist principally of electrodeposited iron. Under the conditions ${ }^{1}$ there used it requires a total of about 96 hours to deposit the desired thickness of nickel $(0.4 \mathrm{~mm}$ or 0.015 in.) and of iron ( $5 \mathrm{~mm}$ or $0.20 \mathrm{in}$.). Ordinarily, this period is not objectionable, but when new designs are to be issued, it takes a considerable period to produce a sufficient number of plates (at least four) to start the printing operations. For such purposes it would be desirable to greatly increase the speed of deposition, preferably to at least four times the present rate. Methods for the rapid deposition of nickel and iron were therefore investigated.

The results ${ }^{2}$ obtained with nickel showed that relatively smooth soft, ductile deposits can be produced from concentrated solutions of nickel sulphate $(4 N)$, at a low $\mathrm{pH}(\mathrm{pH}=1)$, a high temperature $\left(100^{\circ} \mathrm{C}\right)$, and current densities up to $30 \mathrm{amp} / \mathrm{dm}^{2}\left(280 \mathrm{amp} / \mathrm{ft}^{2}\right)$, which is about 15 times the current density regularly employed for this process. Corresponding deposits from chloride solutions are harder and more brittle.

The present paper describes the experiments on iron deposition. As the very rapid deposition of both nickel and iron requires special equipment and more critical control, these processes are not in regular use at the Bureau of Engraving and Printing, but they can be applied if necessary.

${ }^{1}$ C. T. Thomas and W. Blum. The production of electrolytic iron printing plates. Trans. Am. Electrochem. Soc. 57, $59(1930)$.

${ }_{2}^{2} \mathrm{~W}$. Blum and $\mathrm{C}$. Kasper. The structure and physical properties of nickel deposited at high current densities. Trans. Faraday Soc. 31, 1203 (1935). 


\section{REVIEW OF LITERATURE}

The earlier publications on iron deposition were reviewed by W. E. Hughes, ${ }^{3}$ and more recent applications were discussed by Thomas and Blum. ${ }^{4}$ A very complete discussion and bibliography of iron deposition, with special reference to the preparation of pure iron, will be found in a recent monograph. ${ }^{5}$ As most of these studies involved deposition at relatively low current densities, they have no direct relation to the present problem.

\section{SCOPE OF INVESTIGATION}

The purpose of this investigation was to define the conditions for depositing smooth, soft, ductile iron at current densities of at least $10 \mathrm{amp} / \mathrm{dm}^{2}\left(93 \mathrm{amp} / \mathrm{ft}^{2}\right)$ and preferably higher, in contrast to the present practice of about $6 \mathrm{amp} / \mathrm{dm}^{2}\left(56 \mathrm{amp} / \mathrm{ft}^{2}\right)$. This was accomplished by first conducting a large number of exploratory experiments, the deposits from which were tested manually by bending. The conditions found to yield suitable properties were then employed for the preparation of larger specimens, of which the indentation hardness, tensile strength, and ductility were measured. The quantitative tests were limited to deposits that did not crack during deposition or during removal from the underlying steel.

The principal factors investigated were the composition, concentration and $\mathrm{pH}$ of the baths, the temperature and current density, and the type of diaphragm. The experiments were confined to chloride baths, because they have better conductivities than do sulphate baths, and because preliminary tests showed that (unlike nickel) ductile iron can be rapidly deposited from chloride solutions.

\section{EXPLORATORY EXPERIMENTS}

\section{CONDITIONS EMPLOYED}

It was found necessary to conduct even the exploratory experiments on a relatively large scale. Iron deposition is one process in which it is difficult to reproduce on a very small scale the results obtained in larger vessels. For example, it is not possible to duplicate in 1liter jars the type of deposits regularly produced at the Bureau of Engraving and Printing. This difference may be caused partly by the greater ease of oxidation of ferrous solutions in the small vessels, and partly by the difference in circulation when diaphragms are used in small and in large vessels.

Most of the experiments were made in a rectangular cast-iron tank holding about 10 liters, which was lined with acid-proof enamel. The enameled tank was placed in a larger metal tank containing water, which in turn was heated by current passing through resistance wires surrounding the outer tank. The water level in the latter was maintained with a siphon. When necessary, for example at very high current densities, cold water was introduced into the water bath. It was thereby possible to control the temperature in the iron bath within close limits from 60 to $108^{\circ} \mathrm{C}$ (140 to $226^{\circ} \mathrm{F}$ ) for any desired period. As the boiling point of the solution was approached the temperature could be kept more nearly constant.

3 Trans. Am. Electrochem. Soc. 40, 185 (1920).

See reference 1.

H. E. Cleaves and J. G. Thompson. The Metal-Iron. Alloys of Iron Research Monograph Series. (McGraw-Hill Book Co., New York, 1935). 
The anodes were of Armco iron, surrounded by asbestos diaphragms in order to prevent particles from passing into suspension and causing rough deposits.

Diaphragms of light weight, loose cloth of either blue or white asbestos are successfully used in the regular iron baths at current densities up to $6 \mathrm{amp} / \mathrm{dm}^{2}$ (56 amp/ $\left./ \mathrm{ft}^{2}\right)$. This cloth was, however, not suitable for use with more acid solutions and higher temperatures and current densities. After numerous trials it was found that the best material for the latter conditions is dense cloth made of blue African asbestos (crocidolite). Satisfactory imported cloth of this material had 36 threads per inch in direction $A$, and 12 threads in direction $B$, with 2-ply yarns in each direction, a 4 -harness weave, $2 / 2$ twill, and a weight of $65 \mathrm{oz} / \mathrm{yd}^{2}$. When necessary, this was sewed with thread made of similar asbestos.

The cathodes were flat steel plates that had been nickel-plated adherently, rubbed with graphite, and plated with a thin $(0.0025 \mathrm{~mm}$ or $0.001 \mathrm{in}$.) separable layer of nickel. The deposits for the preliminary tests were about $0.25 \mathrm{~mm}(0.01 \mathrm{in}$.) thick.

Special care was required to maintain any specified conditions, especially during the beginning of a run, when the temperature and acidity tend to change rapidly. The technique finally adopted was to heat the bath externally to about $90^{\circ} \mathrm{C}$, introduce a "dummy" cathode of the same size as the regular cathode into the solution, which was made slightly more acid than was desired in the final run, and pass the specified current until the desired temperature and acidity were attained. (If necessary, adjustments of the heating current were made during this "breaking in" process.) The current was then increased for a few minutes to raise the temperature slightly. By the time the dummy cathode was removed and the regular cathode inserted, the conditions were those desired, which could then be maintained during the run.

The acidity was maintained constant by suitable additions of hydrochloric acid at intervals of about 20 minutes. In the preliminary experiments water to replace that lost by evaporation was added between the runs.

The ferrous chloride and other chemicals were of commercial grades that were found to be nearly pure. The small amount of ferric chloride always present in the ferrous salt was reduced by adding hydrochloric acid and introducing strips of pure iron. This also removed copper, lead, and most other heavy metals that might be present. To avoid introduction of copper into the bath the copper bus bars were heavily nickel-plated.

\section{RESULTS}

A large number of exploratory experiments led to the following conclusions regarding the favorable conditions for producing ductile iron at high current densities:

1. The solution should be clear green in color, i. e., nearly free from ferric salts. Ferric salts reduce the cathode efficiency and tend to cause brittle deposits.

2. A high concentration of ferrous chloride is desirable, at least $4 \mathrm{~N}$ and preferably $5 N$. With lower concentrations more brittle deposits are obtained. 
3. The acidity (rather than the $\mathrm{pH}$ ) should be controlled within fairly close limits. Insufficient free acid leads to brittle deposits, while excess acidity lowers the cathode efficiency.

4. Ductile metal can be produced at high efficiencies. The maximum observed was about 85 percent. Considerable gas is evolved, and adequate ventilation is required to protect the operators.

5. Calcium chloride has no appreciable effect on the deposits.

6. Addition of potassium chloride leads to brittle deposits.

7. The temperature is the most important single factor, as variations of $5^{\circ} \mathrm{C}\left(9^{\circ} \mathrm{F}\right)$ may produce a marked change in the properties. In general, under given conditions, a decrease in temperature decreases the ductility. For example, in a $4 \mathrm{~N}$ ferrous chloride solution with $0.1 \mathrm{~N}$ free $\mathrm{HCl}$, a temperature of at least $100^{\circ} \mathrm{C}$. $\left(212^{\circ} \mathrm{F}\right)$ is required for ductile deposits at $20 \mathrm{amp} / \mathrm{dm}^{2}\left(186 \mathrm{amp} / \mathrm{ft}^{2}\right)$, and a temperature of $105^{\circ} \mathrm{C}\left(221^{\circ} \mathrm{F}\right)$ at $30 \mathrm{amp} / \mathrm{dm}^{2}\left(280 \mathrm{amp} / \mathrm{ft}^{2}\right)$.

\section{QUANTITATIVE TESTS}

\section{CONDITIONS EMPLOYED}

For reliable tensile and hardness tests, smooth deposits at least $20 \mathrm{~cm}$ ( 8 in.) long and with a uniform thickness of at least $0.75 \mathrm{~mm}$ (0.03 in.) are required. These were made in the enameled tanks previously described, but with additional precautions.

To obtain uniform current distribution, shields were employed. Each shield consisted of a glass plate in which was cut a rectangular opening that was slightly smaller than the cathode. When this shield was placed parallel to and a short distance from the cathode it prevented an excessive current density on the edges of the cathode. High local current densities are objectionable, not only because they yield a nonuniform thickness of deposit, but also because any "trees" that grow on the edges are likely to become detached and to give rise to small metal particles that cause roughness over the rest of the surface.

Similarly, it was necessary to support the asbestos diaphragms around the anodes in order to keep them parallel to the electrodes and thus yield uniform current distribution. Strips of cypress wood were used for this purpose. The wood was slightly attacked and some organic matter may have entered the solution. If so, it might be expected to yield brittle deposits. Actually, however, no such effects of the cypress could be detected in qualitative tests. The quantitative results are comparable, even though their absolute values may have been slightly affected.

To produce deposits of the prescribed thickness required from 3 to 8 hours of deposition. To maintain uniform conditions over such periods automatic control was applied. The acid was added through a calibrated capillary, and the rate of flow was controlled by adjusting the height of the reservoir bottle. To prevent stoppage of the capillary, the acid was filtered through a sealed-in alundum thimble. Water was added continuously by means of a sealed flask with a constant-level device and a capillary tube. It was necessary to maintain the current constant by manual adjustment, owing to slight fluctuations in the generator voltage. 
By taking the above precautions, it was found possible in most cases to produce deposits suitable for testing. However, some of the deposits had a few rough spots, and others had some pits. The tendency for the latter could be reduced by approaching the specified temperature from above. Only those specimens that were practically free from either projections or pits could be used in tensile tests, but the hardness measurements could be made on almost all of the specimens, at points free from surface defects. Moreover, as each of the recorded values for hardness usually represents the average of 10 or more measurements, the values are more significant than the tensile strength.

\section{RESULTS}

In general, the quantitative tests confirmed the qualitative observations recorded in the discussion of the exploratory experiments. The principal conclusions are illustrated in tables 1,2, and 3. Each value for tensile strength and elongation represents the average of two or more measurements from selected specimens. The agreement of duplicate runs on tensile tests was very good, but the elongation values were more erratic, except in the case of exceptionally perfect and ductile specimens. The Brinell number was determined with a $15-\mathrm{kg}$ load, $1 / 16$-inch $(1.55-\mathrm{mm})$ ball, and a period of 30 seconds. Unless otherwise noted, the baths contained simply ferrous chloride approximately $5 \mathrm{~N}$, that is, $497 \mathrm{~g} /$ liter or $66 \mathrm{oz} / \mathrm{gal}$ of $\mathrm{FeCl}_{2} .4 \mathrm{H}_{2} \mathrm{O}$; and hydrochloric acid in the concentration designated under "acidity." $(0.1 N \mathrm{HCl}$ is equivalent to $3.6 \mathrm{~g} / \mathrm{liter}$ or $0.5 \mathrm{oz} / \mathrm{gal}$ of $\mathrm{HCl}$; or to 10 $\mathrm{ml} /$ liter or $0.13 \mathrm{fl} \mathrm{oz/gal}$ of concentrated hydrochloric acid, sp gr 1.18). When boric acid was added (for example, $0.5 \mathrm{M}$, equal to $30 \mathrm{~g} /$ liter or $4 \mathrm{oz} / \mathrm{gal}$ of $\mathrm{H}_{3} \mathrm{BO}_{3}$ ), the acidity was still expressed in terms of the hydrochloric acid.

TABLE 1.-Effect of temperature on physical properties

$\left(5 \mathrm{~N} \mathrm{FeCl}_{2}\right)$

At $10 \mathrm{amp} / \mathrm{dm}^{2}\left(93 \mathrm{amp} / \mathrm{ft}^{2}\right)$ and $0.06 \mathrm{~N}$ acidity

\begin{tabular}{|c|c|c|c|c|c|c|}
\hline Experiment & \multicolumn{2}{|c|}{ Temperature } & \multicolumn{2}{|c|}{ Tensile strength } & $\begin{array}{c}\text { Elonga- } \\
\text { tion }\end{array}$ & $\begin{array}{l}\text { Brinell } \\
\text { number }\end{array}$ \\
\hline $\begin{array}{l}B 5 \\
B 3 \\
B 3\end{array}$ & $\begin{array}{r}{ }^{\circ} \mathrm{C} \\
97 \\
100 \\
102\end{array}$ & $\begin{array}{r}{ }^{\circ} \mathbf{F} \\
207 \\
212 \\
216\end{array}$ & $\begin{array}{r}\mathrm{kg} / \mathrm{cm}^{2} \\
5,110 \\
4,270\end{array}$ & $\begin{array}{l}\text { lb/in. } .^{2} \\
73,000 \\
\quad 61,000\end{array}$ & $\begin{array}{l}\text { \% } \\
5 \\
18\end{array}$ & $\begin{array}{l}167 \\
135 \\
127\end{array}$ \\
\hline
\end{tabular}

At $20 \mathrm{amp} / \mathrm{dm}^{2}\left(186 \mathrm{amp} / \mathrm{ft}^{2}\right)$ and $0.10 \mathrm{~N}$ acidity

\begin{tabular}{rr|r|r|r|r|r|r}
\hline$A 6$ & 95 & 203 & 7,910 & 113,000 & 4 \\
13 & 210 \\
182 & 100 & 212 & 5,740 & 82,000 & 72,000 & 16 \\
\hline
\end{tabular}

The results in table 1 show clearly that relatively small changes in temperature have large effects upon the properties of the deposits. In general, a rise in temperature produces softer and more ductile deposits. 
TABLE 2.-Effect of acidity on physical properties

$\left(5 \mathrm{~N} \mathrm{FeCl}_{2}\right)$

At $100^{\circ} \mathrm{C}\left(212^{\circ} \mathrm{F}\right)$ and $20 \mathrm{amp} / \mathrm{dm}^{2}\left(186 \mathrm{amp} / \mathrm{ft}^{2}\right)$.

\begin{tabular}{|c|c|c|c|c|c|}
\hline \multirow[b]{2}{*}{$A_{4} A_{4}-s_{1}$} & \multirow{2}{*}{$\begin{array}{c}N_{N}^{\text {Acidity }} \\
\\
0.04 \\
.10 \\
.13\end{array}$} & \multicolumn{2}{|c|}{ Tensile strength } & \multirow{2}{*}{$\begin{array}{c}\begin{array}{c}\text { Elonga- } \\
\text { tion }\end{array} \\
\% \quad \begin{array}{r}0 \\
13 \\
10\end{array}\end{array}$} & \multirow{2}{*}{$\begin{array}{r}\begin{array}{l}\text { Brinell } \\
\text { number }\end{array} \\
\\
\\
228 \\
182 \\
169\end{array}$} \\
\hline & & $\begin{array}{r}\mathrm{kg} / \mathrm{cm}^{2} \\
7,630 \\
5,740 \\
4,760\end{array}$ & $\begin{array}{r}1 \mathrm{~b} / \mathrm{in} .{ }^{2} \\
109,000 \\
82,000 \\
68,000\end{array}$ & & \\
\hline
\end{tabular}

From table 2 it may be seen that an increase in acidity lowers the hardness and tensile strength and increases the ductility. Practically, it is difficult to make satisfactory deposits under given conditions over a wide range of acidity. If the latter is very low, the deposits crack during deposition, and if it is too high, the efficiency falls off very rapidly, but no embrittlement of the deposits is observed. In general, similar, if not identical, properties are obtained by varying the acidity in the same direction and proportion as the current density. This is illustrated in table 3.

TABLE 3.-Effect of current density and acidity at $102^{\circ} \mathrm{C}\left(216^{\circ} \mathrm{F}\right)$

$\left(5 \mathrm{~N} \mathrm{FeCl}_{2}\right)$

\begin{tabular}{|c|c|c|c|c|c|c|c|}
\hline Experiment & $\underset{N}{\operatorname{Acidity}}$ & Current & density & Tensile & rength & $\begin{array}{c}\text { Elonga- } \\
\text { tion }\end{array}$ & $\begin{array}{c}\text { Brinell } \\
\text { number }\end{array}$ \\
\hline $\begin{array}{l}A 7, A 8 \\
A 15\end{array}$ & $\begin{array}{r}0.06 \\
.10 \\
.15\end{array}$ & $\begin{array}{r}\mathrm{amp} / \mathrm{dm}^{2} \\
10 \\
20 \\
30\end{array}$ & $\begin{array}{r}\mathrm{amp} / \mathrm{ft}^{2} \\
93 \\
186 \\
280\end{array}$ & $\begin{array}{r}\mathrm{kg} / \mathrm{cm}^{2} \\
4270 \\
5740 \\
5110\end{array}$ & $\begin{array}{l}\mathrm{lb} / \mathrm{in} .{ }^{2} \\
61,000 \\
82,000 \\
73,000\end{array}$ & $\begin{array}{r}\% \\
18 \\
13 \\
5\end{array}$ & $\begin{array}{l}135 \\
182 \\
155\end{array}$ \\
\hline
\end{tabular}

For these reasons it is difficult to make satisfactory deposits at a fixed temperature and acidity over a wide range of current density. In general, it was found that an increase in current density produced harder and less ductile deposits.

The quantitative results did not show any marked effects of either boric acid $\left(0.5 \mathrm{M}\right.$, i.e., $30 \mathrm{~g} /$ liter or $4 \mathrm{oz} / \mathrm{gal}$ of $\left.\mathrm{H}_{3} \mathrm{BO}_{3}\right)$ or of calcium chloride (1.5 N, i.e., $165 \mathrm{~g} /$ /iter or $22 \mathrm{oz} / \mathrm{gal}$ of $\mathrm{CaCl}_{2}$ ). In several experiments, the deposits with boric acid were about 10 Brinell numbers softer than those without boric acid, but there were no consistent effects on the tensile strength or elongation. No definite effects were found with the calcium chloride.

All the deposits produced under the conditions prescribed had relatively fine structures, and there were no such pronounced differences as were observed with hard and soft nickel deposits. In general, greater hardness and tensile strength were accompanied by a finer structure. This relation is illustrated by photomicrographs of typical cross sections in figure 1 .

The fact that the hardest deposits were produced at low acidities or high current densities is consistent with the hypothesis supported by Macnaughtan and his associates ${ }^{6}$ that hardness of nickel or iron deposits is caused by, or associated with, the inclusion of oxides or

\footnotetext{
${ }^{6}$ D. J. Macnaughtan, G. E. Gardam, and R. A. F. Hammond, Trans. Faraday Soc. 29, 729 (1933).
} 


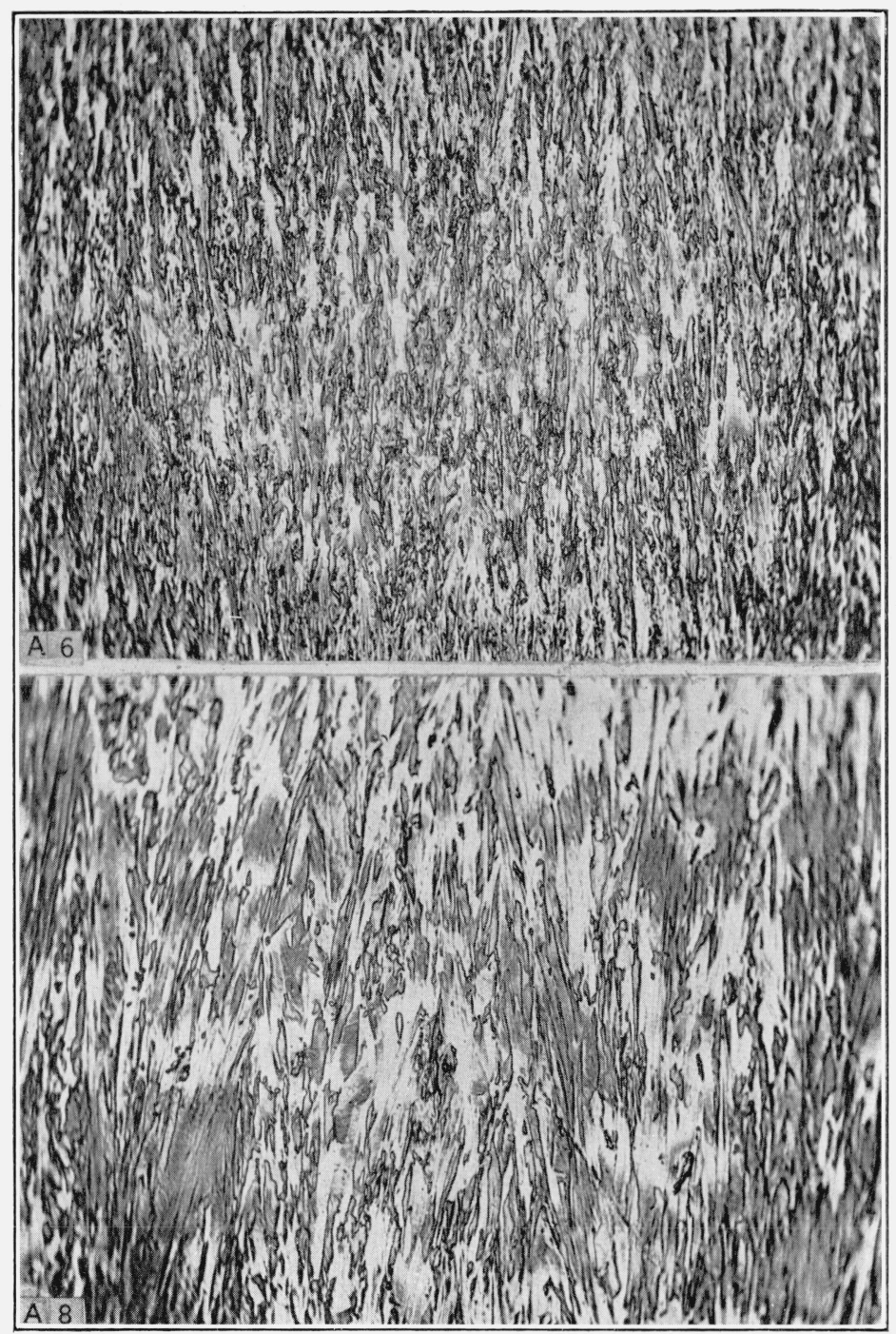

Figure 1.-Structure of typical iron deposits $(\times 500)$.

$\begin{array}{crcccc}\text { No. } & { }^{\circ} \mathrm{C} & \mathrm{amp} / \mathrm{dm}^{2} & \mathrm{~kg} / \mathrm{cm}^{2} & \text { Elongation (\%) } & \text { Brinell no. } \\ A 6 & 95 & 20 & 7,910 & 4 & 210 \\ A 8 & 100 & 10 & 4,270 & 18 & 135\end{array}$ 
basic materials. This hypothesis was confirmed by analysis of two typical deposits by fusion in a vacuum. One of the hardest specimens $(A 6)$ showed an oxygen content of 0.015 percent, and one of the softest $(A 8)$ a content of only 0.005 percent.

\section{CONCLUSIONS}

1. Relatively soft, ductile iron can be deposited from a bath containing $5 \mathrm{~N} \mathrm{FeCl}_{2}$ and $0.10 \mathrm{~N} \mathrm{HCl}$, at a temperature of $106^{\circ} \mathrm{C}\left(222^{\circ} \mathrm{F}\right)$ and a current density of $20 \mathrm{amp} / \mathrm{dm}^{2}\left(186 \mathrm{amp} / \mathrm{ft}^{2}\right)$.

2. Under any given conditions, softer deposits are produced by increasing $(a)$ the acidity or $(b)$ the temperature or by decreasing $(c)$ the current density.

3. Additions of boric acid or of calcium chloride to the baths have little effect on the properties of the deposits.

4. The harder deposits are finer grained and contain more oxygen than the softer deposits.

5. The rapid production of dense, ductile iron deposits, free from roughness or pits, requires very careful control of all factors, especially the acidity and temperature, and the use of effective diaphragms, preferably made of blue asbestos cloth.

The author acknowledges the assistance received in this investigation from T. F. Slattery and C. T. Thomas of the U. S. Bureau of Engraving and Printing, and W. Blum, J. G. Thompson, W. H. Swanger, and C. S. Aitchison of the National Bureau of Standards.

Washington, February 20, 1937. 